\title{
Not too small to be strategic: The state of academic program review guidelines and instrumentation in public institutions
}

\author{
Veronica McGowan, D.Ed. \\ Southwestern Oklahoma State University
}

\begin{abstract}
In higher educational settings, the academic program review process allows academic units to solicit feedback, make data-driven decisions regarding effectiveness and sustainability, and report to stakeholders. In order to discover trends and best practices in the current state of academic program review in higher education, examined was a sample of 53 processes representing a range of small-to-large public institutions in the United States in the categories of associate-degree granting, bachelors-degree granting, and masters-degree granting. Using a content analysis methodology, outcomes assessment and the use of data results featured prominently with $86.7 \%$ of the sample requiring their incorporation in academic program review, followed closely by judgments of resource adequacy and demonstration of program necessity and efficiency.
\end{abstract}

Keywords: Academic Program Review, Strategic Program Development

W hile academic program review (AGR) is a best practice for ensuring academic quality, institutions are moving to make the process more robust by qualifying guidelines and instructions about the process in order to use results for more strategic purposes, such as demonstrating impact. Backlud et al. (2011) note that the American history of academic program reviews is grounded in the assessment and accountability movements started in the 1970s and 1980s, with state legislatures requiring assessment-centered models to demonstrate effectiveness. The Council of Graduate Schools (2005) notes the purposes of academic program review to be, "quality assurance, quality improvement, accountability, identification of strategies for improvement, and information collection and synthesis to facilitate prioritization of resources." Multi-step models are evolving that describe a robust self-study process as involving internal and external expertise to collect and examine evidence that reflects practices, processes, policies, and effectiveness, in response to guidelines or standards such as the Council for Advancement of Standards in Higher Education's (n.d.) seven-step model. Typically, in the most progressive models, after data analysis, actions and strategic planning should allow the academic unit to track changes and demonstrate how it will further its goals. Field-specific models, such as those of the Accreditation Council for Business Schools and Programs (ACBSP, 2017), National Communication Association (NCA, 2009), and the National League of Nursing Accrediting Commission (NLNAC, 2016), are being increasingly used to standardize guidelines, recognize excellence, convey expectations for continuous improvement, and advance the field in teaching, learning, and assessment areas. For academic programs not accredited under a field organization, the expectation of a robust process is expected by regional accreditation bodies, such as the Higher Learning Commission (HLC, 2018), Middle States Commission on Higher Education (MSCHE, 2015), and the Southern Association of Colleges and Schools Commission on Colleges (SACS, 2018), amongst others.

MCGOWAN / DOI: 10.5929/9.1.1 
While data elements of a program review may be benchmarked to gauge comparative progress, the collection of program review data points is difficult to compare due to the complexity of data types and purposes for gathering data; the National Higher Education Benchmarking Institute (n.d.) recommends a mixture of over 150 quantitative and qualitative types of data to capture credited program quality and accurately assess needs and priorities. Given institutional and state system pressures, such as a need to justify program continuance, and influences that make each institutional program review process unique, overall measures may also not provide an accurate reflection of program quality due to time, population, and local factors.

The objective of this study was to analyze differences between materials related to academic program review as posted on institutional websites in order to describe the current state of practices. Overall analysis, as well as analysis by institutional type, allowed frequency percentages to argue each element's inclusion as best practice in implementation. A systematic literature review examines aspects of program review in terms of their recognition as important components. Hopefully, this literature review identifies gaps in program review research that have prevented the empirical study from forwarding effective evaluation and identification of best practices.

\section{Literature Review}

A cyclic academic program review is a focused method for gathering evidence of programmatic practices and policies including inputs, outputs, processes, and mapping between each in a continuous improvement framework. For some institutions and academic field organizations, program review processes are still being formalized, usually to promote accountability, legitimacy and effective change (Sowcik, Lindsey, \& Rosch, 2012; Wu \& Senior, 2016). Increasingly, field literature is advocating for strong connections between program review and strategic planning in order to impact institutional efficiency (Coombs, 2017). In addition, stakeholders are increasingly advocating for alignment between accreditation standards and academic program reviews to foster resource efficiency and directed action (Bowker, 2017). Perhaps the strongest arguments for deploying academic program review is made by those who have conducted empirical studies linking academic program review activity to policies and practices, such as curricular improvements, staffing realignment, support for an outcomes-based assessment model, and unit restructuring (Dougherty \& Reddy, 2013; Novodvorsky et al., 2015; Siems \& Bell, 2018), and institutional impacts, such as increased transparency, accountability and productivity (Harnisch, 2011).

Benchmarking efforts as part of the program review process are historically low (Dickeson, 2010), with Deming and Figilo (2016) noting stakeholder difficulty in identifying benchmark categories and scope. Current communications from regional accreditation bodies still provide instruction on basic benchmarking standards for use in academic programs or allowing institutions to explore benchmarking as a quality improvement initiative (Higher Learning Commission, n.d.; Permenter, 2016), so it is clear that the development of a rich set of metrics is still ongoing for a significant portion of institutions. For institutions, the number of empirical studies exploring the effectiveness of academic program review (APR) is low with only 15 directly related recent studies found. Although particular elements of APR, such as outcomes assessment, are well studied, most field literature on APR is theoretical in the form of published guidelines or standards. The selection and weighting of evaluation indicators is difficult; Praslova (2010) used this contention as a justification to adapt Kirkpatrick's $(1976,1996)$ organizational training evaluation framework.

MCGOWAN / DOI: 10.5929/9.1.1 
An important predecessor to this work is Ewell, Paulson, and Kinzie's (2011) comprehensive study of program level assessment practices in two- and four-year institutions. Findings indicated that for both accredited and non-accredited programs, assessment results were used for program review activity more than any other category, including improving curriculum and instruction. Conclusions from that study revealed the importance that field assessment expectations and internal improvement interests have on assessment practice, including the range and frequency of use of assessment practices related to program reviews.

\section{Purpose of program review}

Numerous stakeholders within the evaluation field offer perspectives towards the purpose of academic program review. Several institutions and field leaders confirm purposes of maintaining or improving program quality (Coppard, et al., 2015; Drexel University, n.d.; Nugent \& LaRocco, 2014; University of Oklahoma, 2009), feasibility, viability, priorities (Morriss-Olson, 2016; University of Illinois at UrbanaChampaign, n.d.), evaluating effectiveness or performance (Backlund et al., 2011; Coppard; et al., 2015; Hanover Research, 2012), and for accountability, reporting, transparency, or data collection purposes (Backlund; et al., 2011; Coppard et al., 2015; Halonen \& Dunn, 2017; Henry et al., 2014). Other field stakeholders link individual program reviews to overall institutional efficiency due to organizational dependency (Miller, 2016; Nelson \& Nicholas, 2012). Despite program review purpose being wellrepresented in literature, critics are noting that program reviews may not be meeting institutional needs due to failure to review purposes and policies, or perceptions by faculty participants of authoritarian and non-collegial processes (Bowker, 2016; Turner, 2016).

\section{Program review as a process}

Similar to AGR purposes, numerous stakeholders illustrate their understanding of an AGR process that represents best practices to be objective (Dee \& Heineman, 2016; Small, 2015), rigorous or systematic (Lopez et al., 2016; Shambaugh, 2017), action-based (Coppard et al., 2015; Henry et al., 2014), and reflective of qualitative and quantitative data (Henry et al., 2014). Field literature and portrayals seem to agree that the process usually involves the institution setting a purpose, stating requirements, and holding stakeholders to a schedule and framework, such as collecting data and gathering input for a self-study (Cornell University, n.d; Hanover Research, 2012; University of Texas at Dallas, 2016). Reported outcomes are expected to reflect analysis with Ryan (2015) suggesting that commonly assessed items that include learning design, content and pedagogy in a feedback-heavy framework with an emphasis on facultystudent interactions. Finally, the field seems to recognize that recommendations, strengths, weaknesses, and opportunities should be identified with internal review to foster stakeholder engagement and external review to validate findings. In fact, the data-driven aspect of AGR may serve as one of its most important processes, especially given faculty concerns about their voices in the decision-making process (Schoepp \& Tezcan-Unal, 2016) and the charge of implementing actions based on data (Schoepp \& Benson, 2015).

Field literature seems to suggest that process-related elements of program review still lack best-practice models and recommendations with findings from Wickham (2017) that ownership and alternative use of data are issues in some sample populations. In addition, Nicholson (2011) notes that learning or educational theory are infrequently linked to improvement processes.

\section{Stakeholder involvement}

Bresciani (2006) noted that higher education's adoption of continuous quality improvement practices may have had the unintended effect of isolating faculty from processes, despite an accrediting body's efforts

MCGOWAN / DOI: 10.5929/9.1.1 
to expect or require their participation. With the shift in focus to an expectation that student outcomes are central to academic assessment (Council of Regional Accrediting Commissions (CRAC), 2003), stakeholder involvement has moved from best practice to expected demonstration of nuanced involvement at all process stages (CRAC, 2004) that is increasingly expected to address intellectual, interpersonal and psychological domains (Young, 2018) for broader ranges of stakeholders (Robinson \& Demeter, 2017).

\section{Program evaluation criteria}

Several field theorists have put forward potential criteria for evaluating academic programs. In an update from his 1999 seminal work, Dickeson (2010) suggested ten (10) evaluation criteria, which receive representation in some form in this study's coding form, that is discussed in the methodology section. Wells and Wells's (2011) ten criteria are also well-represented in this study with the expectation of two specific criteria that were considered but excluded due to lack of findings: per student costs were not typically presented and while graduation rates were presented, many institutions did not clearly present rates in terms of commonly noted four-year, five-year, six-year time frames. In addition, performance funding formulas are having an impact on the mechanisms that higher education uses to addresses budget allocation (Dougherty \& Reddy, 2013), so field discussion indicates that impact indicators will have an outsize effect on determinations.

In conclusion, reviewed literature makes clear that due to the complexity of analyzing and benchmarking quantitative and qualitative data sets, academic program review effectiveness is best examined through the effectiveness of its elements, particularly those that reflect outcomes assessment and data-driven decision making.

\section{Methodology}

Content analysis is deployed in this research as a robust methodology of qualitative studies, for its flexible way of discovering patterns in data manifestations (Stemler, 2015), and has been widely used in research relating to the presentation of education settings (Leach \& Ramachandran, 2018). Data was collected about 53 independent program review processes that represented a diversity of regional settings in small, medium, and large community colleges, state colleges, and universities of the American public education system. Very large public institutions were excluded from the study due to pilot findings and field literature (Audretsch, 2014; Geiger, 2017; Johnson et al., 2016) that suggested that the independent structure of individual colleges with their inherent research structure and robustness of funding, including commercial and technological partnerships, means that APR will reflect strategic development of the college unit instead of the institution. Therefore, to maintain focus on institutional strategic development, the convenience sample consisted of public institutions of six states representing the United States regional categories with the listing culled from the appropriate state department of education, deploying a convenience selection of three institutions from each institutional category of associate-degree granting, bachelor-degree granting, and masters-degree granting. Inclusion in the sample mandated at least one relevant finding; therefore, findings presentation will be in terms of prevalence. All materials collected were from public areas of institutional websites in order to inform discussion on the transparency of the process. As Volkwein (2010) confirmed, most higher education institutions have an APR system in place; however, the materials guiding that process may not be public, hence the need for convenience sampling method. Although search terms involved "program review," "self-study," and extensive searches of Academic Affairs pages, the scope of this investigation also included degree and major reviews, as long as it was clear that the review was a comprehensive study that included outcomes

MCGOWAN / DOI: 10.5929/9.1.1 
assessment and was intended as a review that considered program viability, not just an evaluation of departmental effectiveness. Consensus between raters confirmed that each evaluated artifact was within the defined scope of the study. Each coder was assigned to independently code each site; interrater reliabilities were calculated with an average of $\mathrm{K}=.70$ (Stemler, 2004). Inclusion of the prevalence findings presented in the next section was contingent on the level of agreement between coders.

The coding instrument developed through three iterations: the first version developed in response to the literature review findings and the second developed to adapt to a pilot study of six program review processes culled from institutions of the reviewer's home state. The end of the pilot study yielded the final instrument, which reflects active findings of the field. Items on the coding form included categories about the purpose of the program review, designated roles and responsibilities of stakeholders, related timeline information, provision of a program or departmental vision or mission, and information regarding review of past recommendations. The form also sought information about program student learning outcomes, program description and history, program goals, outcomes, and curriculum mapping. Other items on the form sought program demographics such as enrollment, student diversity, faculty profiles, as well as information about faculty research and advising interests. A category of effectiveness indicators relating to budget, benchmarks, resource allocation, facility, staffing, and technology adequacy was also cataloged. Finally, program strategic and action planning, overall functioning, leadership and policy development, and the use of indirect measures formed categories. A meta-information section sought information about internal and external reviews, scheduling, sponsorship, and portfolio requirements. Most ratings were dichotomous (required or not required), with significance calculated from the frequency. Two coders, a research professional, and a student trained in the use of the coding instrument completed the evaluation of program review information.

Table 1 - Meta information about the program review

\begin{tabular}{|c|c|c|c|c|c|}
\hline & All & & Associates & Bachelors & Masters \\
\hline Self-study & $88.6 \%$ & & $66.6 \%$ proposals & $17 \%$ proposals & 0\% proposals \\
\hline Purpose & $83 \%$ & & $44 \%$ not provided & & \\
\hline Quality & $49 \%(26)$ & & $15 \%(7)$ & $15 \%(7)$ & $23.4 \%(11)$ \\
\hline Accountability & $35.8 \%(19)$ & & $8.5 \%(4)$ & $10.6 \%(5)$ & $10.6 \%(5)$ \\
\hline Effectiveness & $30 \%(16)$ & OF & $12.7 \%(6)$ & $8 \%(4)$ & $15 \%(7)$ \\
\hline Guidance & $26.4 \%(14)$ & THOSE... & $10.6 \%(5)$ & $10.6 \%(5)$ & $17 \%(8)$ \\
\hline $\begin{array}{l}\text { Student } \\
\text { Achievement }\end{array}$ & $15 \%(8)$ & & $6.3 \%(3)$ & $6.3 \%(3)$ & $15 \%(7)$ \\
\hline $\begin{array}{l}\text { Time frame } \\
\text { (average) }\end{array}$ & $\begin{array}{l}5.3 \text { years } \\
17 \% \text { not } \\
\text { provided; }\end{array}$ & & $\begin{array}{l}3.47 \text { years } \\
55 \% \text { not provided }\end{array}$ & 5.83 years & 5.33 years \\
\hline $\begin{array}{l}\text { Assemble as a } \\
\text { portfolio }\end{array}$ & $40 \%(18)$ & & $27.7 \%(5)$ & $39 \%(7)$ & $33.3 \%(6)$ \\
\hline $\begin{array}{l}\text { Sponsorship } \\
\text { Academic Affairs } \\
\text { Committee } \\
\text { Ins. Effectiveness } \\
\text { Other }\end{array}$ & $\begin{array}{l}51 \%(27) \\
19 \%(10) \\
11.3 \%(6) \\
19 \%(10)\end{array}$ & $\begin{array}{c}\text { OF } \\
\text { THOSE... }\end{array}$ & & & \\
\hline $\begin{array}{l}\text { Public posting of } \\
\text { review schedule }\end{array}$ & $39.6 \%(21)$ & & $38 \%(8)$ & $19 \%(4)$ & $43 \%(9)$ \\
\hline
\end{tabular}

MCGOWAN / DOI: 10.5929/9.1.1 
Table 2 Required Component of program review

\begin{tabular}{|c|c|c|c|c|c|}
\hline & All & & Associates & Bachelors & Masters \\
\hline OA data results & $86.7 \%(46)$ & & $30.4 \%(14)$ & $34.7 \%(16)$ & $34.7 \%(16)$ \\
\hline Resource analysis & $75.4 \%(40)$ & & $35 \%(14)$ & $32.5 \%(13)$ & $32.5 \%(13)$ \\
\hline Program necessity & $75.4 \%(40)$ & & $40 \%(16)$ & $27 \%(11)$ & $32.5 \%(13)$ \\
\hline Stated SLOs & $73.5 \%(39)$ & $\begin{array}{c}\text { OF } \\
\text { THOSE }\end{array}$ & $30 \%(12)$ & $38 \%(15)$ & $30 \%(12)$ \\
\hline Vision\Mission stated & $69 \%(37)$ & & $24 \%(9)$ & $32.4 \%(12)$ & $43.2 \%(16)$ \\
\hline Enrollment & $69 \%(37)$ & & $37 \%(14)$ & $40.5 \%(15)$ & $21 \%(8)$ \\
\hline Faculty demographics & $67.9 \%(36)$ & & $19 \%(7)$ & $44 \%(16)$ & $36 \%(13)$ \\
\hline SWOT analysis & $67.9 \%(36)$ & & $30.5 \%(11)$ & $36 \%(13)$ & $33 \%(12)$ \\
\hline Program description & $66 \%(35)$ & & $25 \%(7)$ & $34 \%(12)$ & $40 \%(14)$ \\
\hline Internal review required & $66 \%(35)$ & & $34 \%(12)$ & $34 \%(12)$ & $31.4 \%(11)$ \\
\hline Long-term planning & $62 \%(33)$ & & $27 \%(9)$ & $33 \%(11)$ & $40 \%(13)$ \\
\hline External review required & $62 \%(33)$ & & $21 \%(7)$ & $36.3 \%(12)$ & $42.4 \%(14)$ \\
\hline Modalities of learning & $56.6 \%(30)$ & & $26.6 \%(8)$ & $36.6 \%(11)$ & $36.6 \%(11)$ \\
\hline Student demographics & $54.7 \%(29)$ & & $27.5 \%(8)$ & $34 \%(10)$ & $38 \%(11)$ \\
\hline Staffing levels, HR plan & $51 \%(27)$ & $\begin{array}{c}\text { OF } \\
\text { THOSE } \\
\ldots\end{array}$ & $33.3 \%(9)$ & $33.3 \%(9)$ & $33.3 \%(9)$ \\
\hline Stated program goals & $47 \%(25)$ & & $32 \%(8)$ & $36 \%(9)$ & $32 \%(8)$ \\
\hline Fiscal soundness & $40 \%(18)$ & & $27.7 \%(5)$ & $27.7 \%(5)$ & $44.4 \%(8)$ \\
\hline Use of indirect measures & $40 \%(18)$ & & $44.4 \%(8)$ & $33.3 \%(6)$ & $22 \%(4)$ \\
\hline Use of benchmarks & $32 \%(17)$ & & $41 \%(7)$ & $35 \%(6)$ & $23.5 \%(4)$ \\
\hline Review of past actions & $28.3 \%(15)$ & & $26 \%(4)$ & $40 \%(6)$ & $33 \%(5)$ \\
\hline Program history & $28.3 \%(15)$ & & $20 \%(3)$ & $33 \%(5)$ & $46 \%(7)$ \\
\hline $\begin{array}{l}\text { Research, scholarly or } \\
\text { creative activity }\end{array}$ & $24.5 \%(13)$ & & $15 \%(2)$ & $46 \%(6)$ & $38 \%(5)$ \\
\hline Advising activity & $20.7 \%(11)$ & & $9 \%(1)$ & $36 \%(4)$ & $54 \%(6)$ \\
\hline Leadership evaluation & $19 \%(10)$ & & $10 \%(1)$ & $20 \%(2)$ & $70 \%(7)$ \\
\hline Curriculum map & $13.2 \%(7)$ & & $42 \%(3)$ & $57 \%(4)$ & $0 \%(0)$ \\
\hline
\end{tabular}

\section{Results}

In Table 1, 88.6\% of the sample use a self-study program review methodology with the remainder deploying a proposal justification structure; $66 \%$ of proposal structures were found at associates-granting institutions. Seventeen percent of the sample did not publically provide a purpose for conducting selfstudies. Improving quality and providing accountability, followed by improving effectiveness, consistently emerged as the most important program review purposes for all institutions and across all institutional categories; some categories show over $100 \%$ as many institutions listed multiple purposes. An average was computed regarding APR time frame with the finding of a longer time frame for field-accredited programs and a shorter time frame for new programs and non-accredited programs. Associate degreegranting institutions had a significantly lower time frame than the other categories, substantiated by their 
greater use of a proposal structure over a self-study structure. Sixty-nine percent of sampled institutions require the APR to address vision\mission-related issues, such as how the department's vision\mission aligns with the institutional vision \mission. Of those, $24 \%$ of associate-granting institutions require APR to address, with $32.4 \%$ of bachelor degree-granting, and $43.2 \%$ of master's degree-granting institutions requiring APR to address. After the time frame category, Table 1 shows the most popular required APR components listed in order of significance. Due to the prevalence of findings, three different categories related to resources (which included the address of adequacy of facilities, technology, and support services) merged into one resource category. Strategic or long-term planning is listed separately from action, or short-term planning, due to expectations of tracking effectiveness.

\section{Discussion}

In general, with over half of this study's identified components being required in at least $60 \%$ of the sample, it seems the field is incorporating program review complexity at greater levels than previous studies found, such as Wu and Senior's (2016). One significant departure is from Conrad and Wilson's 1986 study, which found four models of program review: goal-based, responsive, decision-making, or connoisseurship. While this study's findings included elements of all of these, most program reviews have expanded in size and scope to incorporate multiple perspectives; in fact, coding instrument modification removed identification of a singular model due to multiple findings per institution.

Meta-data findings of an average time frame of 5.3 years for academic program reviews are confirmed in the field literature (Coombs, 2017; Hanover Research, 2012). Regarding the purpose, four main categories (curricular improvement, use in decision-making, accountability, and data-driven) emerged in the studied sample, which despite the passage of 14 years, remained in similar percentages of significance as Allen's (2004) early study. Bers' (2011) recognition of five models of program review were fairly well represented in this study, with findings that $56 \%$ of the sample deployed an External Evaluation or Self-Study Focus Program Review, 33\% used a Mixed Program Review, and 11\% arranged a Standardized Program Review; only Ber's Outside Expert Program Review and Free-Form Program Review did not receive representation in this study.

While meeting accreditation expectations is still the most important reason for examining assessment evidence (Kuh, Jankowski, Ikenberry, \& Kinzie, 2014), this study's findings of evidence-based short- and long-term action and strategic planning indicates that internal uses may be developing into a robust driver of assessment purposes. Bers (2011) recognized the importance of a program description section in a program review, along with a mission and purposes section which was also favored by $88 \%$ of this sample's institutions, theoretically providing a rational for program review. In addition, this sample seems to support Ewell, Paulson, and Kinzie's (2011) findings that quality improvement (49\%) and accountability $(35.8 \%)$ are key reasons for undertaking program review.

The validity of using achievement of student outcomes as a measure of assessing program assessment, as demonstrated by $87.6 \%$ of the sample in this study may indicate the prevalence of the practice in American higher educational settings. While other settings, including Greece and Macedonia (Tsinidou, Gerogiannis \& Fitsilis, 2010; Zoran et al., 2013), deploy indirect methods, such as satisfaction, as a more important quality determinant, the American model may be gaining ground. Recent evidence indicates the adoption of the American model outcomes assessment in Brazil (Melguizo \& Wainer, 2015) and European countries with an elevation of vocational education as a higher educational concern and the role of education in social equity issues (Skolnik, 2015). Kuh, Jankowski, Ikenberry, \& Kinzie's (2014) finding that provosts rank national student surveys as one of the top two methods for assessing student

MCGOWAN / DOI: 10.5929/9.1.1 
outcomes may indicate a change in assessment direction. Recent field studies indicate that the use of outcomes-based assessment is driving improvements in the curriculum (Tam, 2014) and adoption of a wider range of assessment tools and measures (Kuh et al., 2014). Despite the prevalence of learning outcome usage, it is clear that faculty need continued professional development in learning outcomes assessment (Schoepp \& Tezcan-Unal, 2016).

With $73.5 \%$ of institutional program reviews in this sample requiring a statement, review of, or address of student learning outcomes, this study aligns with field data which finds that $84 \%$ of institutions deploy general education student learning outcomes (Kuh, Jankowski, Ikenberry, \& Kinzie, 2014). In addition, Kuh, Jankowski, Ikenberry, \& Kinzie's, (2014) finding, that only $40 \%$ of academic program SLOs are aligned with institutional SLOs, serves to highlight the importance of this study's emphasis of APR's role in the strategic development of the overall institution.

Sample findings regarding a significant number of program reviews requiring identification of unique program attributes seem to align with the field theory that links such characteristics to the program impact on the community (Chalmers \& Di Gardiner, 2015; Moffatt-Bruce, et al., 2017). This study's findings, that $40 \%$ of the sample include some type of resource analysis, highlights the importance of strategically managing resources in environments taxed by funding instability, which is the basis for the rise in performance-based funding mechanisms in the states. Recent research underscores the impact that performance-based funding has on programs with Hillman, Tandberg, and Fryar (2015), linking the policy to an increase in short-term certification production. Coombs' (2017) findings of poor documentation for departmental accountability for implementing feedback is related to this study, which ranked incorporation of feedback at only $40 \%$.

Regarding program review's role in strategy development, this study's findings of $62 \%$ representation show that the field is moving to a two-factor business model of market share and growth as advocated by Fannin and Sran (2017). It is clear that this study's implementation would agree that the centrality of the program to the university and surrounding community are important considerations in program strategic planning as advocated by Bers (2011), and Wells and Wells (2011). While this study makes clear that academic departments do not typically make the difficult call for continuation, an obvious undeclared purpose of program review is for the departments and programs to make the case for continuation. In their literature review, Fannin and Saran (2017) argue that the failure to present relevant evidence is the most prevalent reason for program review failure, with Harper and Vernon (2011) seeming to concur with their linkage of success predictors to strategic importance and impact. While accreditation activity may drive the desire to perform programmatic assessment (Kuh, Jankowski, Ikenberry, \& Kinzie, 2014), only $28.3 \%$ required explicit address of accreditation information in the self-study.

\section{Areas for Future Research}

Despite the prevalence of academic program review, this study found surprisingly few empirical studies that examine its effectiveness or role in strategic development in higher education, which seems to align with field findings of a paucity of research in higher education sustainability studies (Chiong, Mohamad, \& Abdul-Aziz, 2017). One theory is that faculty members have a limited amount of research time in addition to their teaching, advising, committee, service, publication, and other work, and, therefore, wish to engage with research topics tied directly to a field of study or industry, rather than reflect back on organizational structures of higher education: topics devolved into by field theorists Darbyshire, Gustafsson, and Mullersdorf (2015). Another theory is that the recentness of robust organizational structures development in international higher educational settings indicates a previous deficit in a

MCGOWAN / DOI: 10.5929/9.1.1 
population of people available to perform reflective study. Baltaru and Soysal (2018) and Ramirez and Tiplic (2014) would seem to confirm with their cataloging of a recent trend rise of administrative positions and effort in European higher education. Finally, field theorists indicate that historical attitudes of academic knowledge production and resultant lack of funding and productive research climate have impeded overall scholarly production, including that of reflective empirical study (Abouchedid \& Abdelnour, 2015; Darley \& Luethge, 2016; Musiige \& Maassen, 2015).

\section{Conclusion}

It is clear that accreditation and external pressures are forcing higher education to respond to calls for transparent and effective decision making, including support or disengagement of programs that may or may not best serve public interests, such as the development of a modern workforce. While academic program review is a systematic process, the guidelines and structures that support it are informed by the development of best practices. The growing complexity of evaluation guidelines and instruments into a self-study structure reinforced with an independent external review component shows that institutions are attempting to tie the academic review process more strongly to data collection and strategic decision making over previous continuance proposal structures. This study helps make clear that outcomes assessment, and its emphasis on data collection for decision-making purposes, has turned the tide from a best practice to an expected practice. For stakeholders wishing to improve their processes, ensuring that their data collection techniques are robust, planning processes address multiple stakeholders, and personnel has sufficient resources to conduct a thorough review, which will help ensure that those achievements are evaluated objectively and that strengths and weaknesses reveal potential for direction shift.

\section{References}

Abouchedid, K., \& Abdelnour, G. (2015). Faculty research productivity in six Arab countries. International Review of Education, 61(5), 673-690. DOI:10.1007/s11159-015-9518-5

Accreditation Council for Business Schools and Programs (2017). Accreditation standards. Retrieved from https://www.acbsp.org/page/baccalaureate?

Allen, M. J. (2004). Assessing academic programs in higher education. Bolten, MA: Anker Publishing

Audretsch, D. B. (2014). From the entrepreneurial university to the university for the entrepreneurial society. The Journal of Technology Transfer, 39(3), 313-321. DOI:10.1007/s10961-012-9288-1

Backlund, O., Bach, B., Procopio, C., Johnston, D., Mello, B., \& Sypher, H. (2011). NCA program review standards: Background, application, and data. Communication Education, 60(3), 279-295. DOI:10.1080/03634523.2011.553723

Baltaru, R. D., \& Soysal, Y. N. (2018). Administrators in higher education: organizational expansion in a transforming institution. Higher Education, 76(2), 213-229. DOI:10.1007/s10734-017-0204-3

Bers, T. (2011). Program review and institutional effectiveness. New Directions for Community Colleges, 2011(153), 63-73. DOI:10.1002/cc.437

Bowker, L. (2016). Language and quality assurance: A case study highlighting the effects of power, resistance, and countertactics in academic program reviews. TTR: Traduction, Terminologie, Rédaction, 29(2), 177-193. DOI:10.7202/1051018ar

MCGOWAN / DOI: 10.5929/9.1.1 
Bowker, L. (2017). Aligning accreditation and academic program reviews: a Canadian case study. Quality Assurance in Education, 25(3). DOI:10.1108/QAE-11-2016-0061

Bresciani, M. J. (2006). Outcomes-based academic and co-curricular program review: A compilation of institutional good practices: 1st ed. Stylus Publishing. Retrieved from https://iucat.iu.edu/iuk/6684233

Chalmers, D., \& Gardiner, D. (2015). An evaluation framework for identifying the effectiveness and impact of academic teacher development programmes. Studies in Educational Evaluation, 46, 81-91. DOI:10.1016/j.stueduc.2015.02.002

Chiong, K., Mohamad, Z., \& Abdul Aziz, A. (2017). Factors encouraging sustainability integration into institutions of higher education. International Journal of Environmental Science and Technology, 14(4), 911-922. DOI:10.1007/s13762-016-1164-3

Conrad, C. F., \& Wilson, R. W. (1986). Academic program reviews. Las Vegas, NV. Association for the Study of Higher Education. (ERIC Document Reproduction Service No. ED284522)

Coombs, V. (2017, February 7). Institutions should link program reviews to strategic plans. Inside Higher Ed. Retrieved from https://www.insidehighered.com/blogs/call-action-marketing-andcommunications-higher-education/institutions-should-link-program

Coppard, B. M., Schwery, L., Jensen, G., Pieper, M., Danielson, M. A., \& Hicks, S. (2015). Program Review: Leveraging Structure, Process and Virtual Reality (poster 10). Retrieved from https://dspace2.creighton.edu

Cornell University. (n.d). Academic program review process. Division of Budget and Planning. Retrieved from http://irp.dpb.cornell.edu

Council for Advancement of Standards in Higher Education (n.d.). Program review. Retrieved from https://www.cas.edu/programreview

Council of Graduate Schools. (2005). Assessment and review of graduate programs: A policy statement. Council of Graduate Schools. Retrieved from http://cgsnet.org/assessment-and-review-graduateprograms-0

Council of Regional Accrediting Commissions (CRAC). (2003). Regional accreditation and student learning: Principles of good practices. Washington, DC: CRAC. Retrieved from http://www.sacscoc.org

Darbyshire, P., Gustafsson, C., \& Müllersdorf, M. (2016). External scrutiny, faculty research culture and the changing university. Journal of Advanced Nursing, 72(11), 2571-2574. DOI:10.1111/jan.12827

Darley, W. K., \& Luethge, D. J. (2016). The role of faculty research in the development of a management research and knowledge culture in African educational institutions. Academy of Management Learning \& Education, 15(2), 325-344. DOI:10.5465/amle.2013.0337

Dee, J., \& Heineman, W. (2016). Understanding the organizational context of academic program development. New Directions for Institutional Research, 2015(168), 9-35. DOI:10.1002/ir.20158

Deming, D. J., \& Figlio, D. (2016). Accountability in US education: Applying lessons from K-12 experience to higher education. Journal of Economic Perspectives, 30(3), 33-56. Retrieved from https://www.urban.org

MCGOWAN / DOI: 10.5929/9.1.1 
Dickeson, R. C. (2010). Prioritizing academic programs and services (2nd ed.). Jossey-Bass, Inc./John Wiley \& Sons, Inc.

Dougherty, K. J., \& Reddy, V. (2013). Performance funding for higher education: What are the mechanisms? What are the impacts? ASHE Higher Education Report, 39(2). Hoboken: Wiley. Retrieved from https://ccrc.tc.columbia.edu

Drexel University. (n.d.) Academic program review. Retrieved from https://drexel.edu/pheal/assessmenteffectiveness/academic-review/

Ewell, P., Paulson, K., \& Kinzie, J. (2011). Down and in: Assessment practices at the program level. National Institute for Learning Outcomes Assessment. Retrieved from http://www.learningoutcomesassessment.org/documents/NILOAsurveyreport2011.pdf

Fannin, W., \& Saran, A. (2017, Winter). Strategic academic program prioritization: In theory and practice. International Journal of Business \& Public Administration, 14(1) 23-35. Retrieved from Business Source Compete: 127980560

Geiger, R. L. (2017). To advance knowledge: The growth of American research universities. New York: Rutledge. Retrieved from https://www.taylorfrancis.com/books/9781351471824

Halonen, J. S., \& Dunn, D. S. (2017, February 27). Avoiding the potholes of program review. The Chronicle. Retrieved from https://www.chronicle.com/article/Avoiding-the-Potholes-of/239330

Hanover Research. (2012). Best practices in academic program review. Retrieved from http://www.asanet.org

Harnisch, T. L. (July 2011). Performance-based funding: A re-emerging strategy in public higher education financing (policy brief). American Association of State Colleges and Universities. Retrieved from www.aascu.org

Higher Learning Commission (2018). Criteria for Accreditation. Retrieved from https://www.hlcommission.org/Policies/criteria-and-core-components.html

Higher Learning Commission. (n.d.). Quality initiative. Retrieved from https://www.hlcommission.org/Accreditation/quality-initiative.html

Hillman, N. W., Tandberg, D. A., \& Fryar, A. H. (2015). Evaluating the impacts of "new" performance funding in higher education. Educational Evaluation and Policy Analysis, 37(4), 501-519. DOI:10.3102/0162373714560224

Johnson, L., Becker, S. A., Cummins, M., Estrada, V., Freeman, A., \& Hall, C. (2016). NMC horizon report: 2016 higher education edition (pp. 1-50). The New Media Consortium. Download from learntechlib.org.

Kirkpatrick, D. L. (1976). Evaluation of training. In R. L. Craig (Ed.), Training and development handbook: A guide to human resource development (2nd ed., pp. 301-319). New York: McGraw-Hill.

Kirkpatrick, D. L. (1996). Invited reaction: Reaction to Holton article. Human Resource Development Quarterly, 7, 23-25. DOI:10.1002/hrdq.3920070104

Kuh, G., \& Ikenberry, S. (2009, October). More than you think, less than we need: Learning outcomes assessment in American higher education. Urbana, IL: University of Illinois and Indiana University,

MCGOWAN / DOI: 10.5929/9.1.1 
National Institute for Learning Outcomes Assessment. Retrieved from: http://www.learningoutcomesassessment.org/ NILOAsurveyresults09.htm

Kuh, G. D., Jankowski, N., Ikenberry, S. O., \& Kinzie, J. L. (2014). Knowing what students know and can do: The current state of student learning outcomes assessment in US colleges and universities. Urbana, IL: National Institute for Learning Outcomes Assessment. Retrieved from http://www.learningoutcomeassessment.org

Leach, J., \& Ramachandran, S. (2018). Discourse analysis of higher education website content. Language, Literature and Culture, (1): 6-10. Retrieved from http://www.aascit.org/journal/llc

Lopez, J. S., Yañez, M. A. S., Salgado, M. D. R. M., \& Vergara, M. D. L. R. (2016). Unified perspective for categorization of educational quality indicators from an accreditation process view-relationships between educational quality indicators defined by accrediting agencies in México at the institutional and program level, and those. International Journal of Higher Education, 5(2), 113. DOI:10.5430/ijhe.v5n2p113

Melguizo, T., \& Wainer, J. (2016). Toward a set of measures of student learning outcomes in higher education: Evidence from Brazil. Higher Education: The International Journal of Higher Education Research, 72(3), 381-401. DOI:10.1007/s10734-015-9963-x

Middle States Commission on Higher Education. (2015). Standards for accreditation and requirements of affiliation. Retrieved from http://www.msche.org/publications/RevisedStandardsFINAL.pdf

Miller, B. A. (2016). Assessing organizational performance in higher education. John Wiley \& Sons. DOI: 10.1057/palgrave.ijea.2150075

Moffatt-Bruce, S. D., Hefner, J. L., Mekhjian, H., McAlearney, J. S., Latimer, T., Ellison, C., \& McAlearney, A. S. (2017). What is the return on investment for implementation of a crew resource management program at an academic medical center? American Journal of Medical Quality, 32(1), 5-11. DOI:10.1177/1062860615608938

Morriss-Olson, M. (2016, July 18). Feasibility checklist: The science of bringing new academic programs to life. Academic Impressions. Retrieved from https://www.academicimpressions.com

Musiige, G., \& Maassen, P. (2015). Faculty perceptions of the factors that influence research productivity at Makerere University. Chapter 6: Knowledge Production and Contradictory Functions in African Higher Education, 109-127. Retrieved from https://zenodo.org/record/824663\#.W8YMM3tKhhE

Nelson, K. A., \& Nicholas, M. C. (2012, Winter). Universitywide program review: Evolving a process for program improvement and institutional planning. Association for Institutional Research, 128. Retrieved from http://www.airweb.org/EducationAndEvents/Publications/ProfessionalFiles/Documents/128.pd $\underline{f}$

National Communication Association (2009). Program Review and Assessment Guidelines. Retrieved from https://www.natcom.org/academic-professional-resources/chairs-corner/program-review-andassessment

National Higher Education Benchmarking Institute (n.d). Benchmarks for community colleges. Retrieved from https://nccbp.org/benchmarks 
National League of Nursing Accrediting Commission (2016). Accreditation Standards for Nursing Education Programs. Retrieved from http://www.nln.org/newsroom/news-releases/newsrelease/2014/12/02/nln-commission-for-nursing-education-accreditation-(nln-cnea)-releasesdraft-standards-for-accreditation-for-review-and-feedback

Nicholson, K. (2011). Quality assurance in higher education: A review of the literature. Unpublished report, McMaster University, Hamilton, Canada. Retrieved from http://cll.mcmaster.ca/COU/pdf/Quality\%20Assurance\%20Literature\%20Review.pdf

Novodvorsky, I., Tomanek, D., Foor, R., \& Burd, G. (2015). Supporting and evaluating learning outcomes assessment through academic program reviews. Assessment Update, 27(4), 4-16. DOI:10.1002/au.30027

Nugent, E., \& LaRocco, S. (2014). Comprehensive review of an accelerated nursing program: A quality improvement project. Dimensions of Critical Care Nursing: DCCN, 33(4), 226-33. DOI:10.1097/DCC.0000000000000054

Permenter, A. (2016). Academic program review: From critical processes to implementation. Southern Association of Colleges and Schools Commission on Colleges, $121^{\text {st }}$ Annual Meeting. Retrieved from http://www.sacscoc.org/2016amho/CS\%20Handouts/CS-62 Permenter.pdf

Ramirez, F, \& Tiplic, D. (2014, April). In pursuit of excellence? Discursive patterns in European higher education research. Higher Education, 67(4), 439-455. DOI: 10.1007/s10734-013-9681-1

Robinson, C., Demeter, E., Frederick, J. G., \& Sanders, C. (2017). When the call comes, keep calm and assess on: Using the EIA Designation Rubric as a self-study for improvement. NILOA Assessment in Practice. Retrieved from http://www.learningoutcomeassessment.org/documents/AssessmentInPractice EIA UNC.pdf

Schoepp, K., \& Benson, S. (2016). Meta-assessment: Assessing the learning outcomes assessment program. Innovative Higher Education, 41(4), 287-301. DOI:10.1007/s10755-015-9347-2

Schoepp, K., \& Tezcan-Unal, B. (2017). Examining the effectiveness of a learning outcomes assessment program: A four frames perspective. Innovative Higher Education, 42(4), 305-319. DOI:10.1007/s10755-016-9384-5

Shambaugh, N. (2017). Ongoing and systematic academic program review. In Handbook of research on administration, policy, and leadership in higher education (pp. 141-156). IGI Global. Retrieved from DOI:10.4018/978-1-5225-0672-0.ch007

Siems, A., \& Bell, M. (2018). Utilizing specialty in training examinations and annual program review to improve program curriculum. Academic Pediatrics, 18(5), 16. DOI:10.1016/j.acap.2018.04.050

Skolnik, M. (2016). How do quality assurance systems accommodate the differences between academic and applied higher education? Higher Education: The International Journal of Higher Education Research, 71(3), 361-378. DOI:10.1007/s10734-015-9908-4

Small, E. (2015). The UMass Amherst sustainability external review process. Conference proceedings of the 11th annual Northeast Campus Sustainability Consortium (NECSC). Retrieved from https://scholarworks.umass.edu/necsc2015/16/

Southern Association of Colleges and Schools Commission on Colleges. (2018). Accrediting Standards. Retrieved from http://www.sacscoc.org/principles.asp 
Sowcik, M., Lindsey, J., \& Rosch, D. (2012). A collective effort to understand formalized program review. Journal of Leadership Studies, 6(3), 67-72. DOI:10.1002/jls.21259

Stemler, S. E. (2004). A comparison of consensus, consistency, and measurement approaches to estimating interrater reliability. Practical Assessment, Research \& Evaluation, 9, 4. Retrieved from https://pareonline.net/getvn.asp?v=9\&n=4

Stemler, S. E. (2015). Content analysis. Emerging Trends in the Social and Behavioral Sciences: An Interdisciplinary, Searchable, and Linkable Resource, 1-14. DOI:10.1002/9781118900772.etrds0053

Tam, M. (2014). Outcomes-based approach to quality assessment and curriculum improvement in higher education. Quality Assurance in Education, 22(2), 158-168. DOI:10.1108/QAE-09-2011-0059

Tsinidou, M., Gerogiannis, V., \& Fitsilis, P. (2010). Evaluation of the factors that determine quality in higher education: an empirical study. Quality assurance in Education, 18(3), 227-244. DOI:10.1108/09684881011058669

Turner, L. N. (2016). Quality assurance in online graduate education: program review processes and assessment techniques used in higher education. Dissertation from the University of Arkansas, Arkansas, United States. Retrieved from https://scholarworks.uark.edu/etd/1459

University of Illinois at Urbana-Champaign. (n.d.). Academic program review. Retrieved from https://provost.illinois.edu/assessment/academic-program-review/\#sthash.c04mU9za.dpbs

University of Oklahoma. (2009). Academic program review. Chapter 3-Academic Affairs. Retrieved from https://www.okhighered.org/state-system/policy-procedures/Chapter\%203-\%202010\%20Final3.pdf\#page $=74$

University of Texas at Dallas (2016). Academic program review- UTDPP1013. Retrieved from https://policy.utdallas.edu/utdpp1013

Volkwein, J. F. (2010). The assessment context: Accreditation, accountability, and performance. New Directions for Institutional Research, 2010(S1), 3-12. DOI:10.1002/ir.327

Wells, R., \& Wells, C. (2011). Academic program portfolio model for universities: Guiding strategic decisions and resource allocations. Research in Higher Education Journal, 11, 1. Retrieved from http://www.aabri.com/manuscripts/11745.pdf

Wickham, S. (2017). Implementing a standardised annual programme review process in a third-level institution. Quality Assurance in Education, 25(3). DOI:10.1108/QAE-05-2015-0021

Wu, K., \& Senior, H. (2016). Business librarians and new academic program review. Journal of Business \& Finance Librarianship, 21(2), 114-134. DOI:10.1080/08963568.2016.1140547

Young, D. G. (2018). Outcomes assessment and sophomore programs: How assessment as organizational learning can improve institutional integrity. New Directions for Higher Education, 2018(183), 4757. DOI:10.1002/he.20292

Zoran, I., Ace, M., Nadica, I., \& Saso, K. (2013). Development and improvement of business higher education through implementation of students learning outcomes assessment plan (SLOAP). UTMS Journal of Economics, 4(1), 1-16. (2013). Retrieved from http://utmsjoe.mk

About the Author

MCGOWAN / DOI: 10.5929/9.1.1 
Veronica McGowan (veronica.mcgowan@swosu.edu) serves as the Activity Director of the Student Success Center at Southwestern Oklahoma State University. Dr. McGowan currently serves as co-chair of the Open Educational Resources Consortia for the Oklahoma State Regents of Higher Education's Council of Online Learning and chair of the Oklahoma Open Textbooks and Open Educational Resources Pilot Program. She is the Vice President of the Board of Education at the Insight School of Oklahoma, a public virtual charter school for grades 7-12 in Midwest City, Oklahoma and currently serves as an Assessment Academy Mentor with the Higher Learning Commission (HLC) and as an Evaluation Reviewer and Assessment Expert for the Accreditation Council for Business Schools and Programs (ACBSP). 